\title{
Initial Growth of Eremanthus incanus (Less.) Less in Soil with Manganese
}

\author{
Fillipe Vieira de Araújo ${ }^{1}$, Enilson de Barros Silva ${ }^{2}$, Alexandre Christófaro Silva ${ }^{2}$, \\ Maurício Soares Barbosa ${ }^{3}$, Bárbara Olinda Nardis ${ }^{4}$, Israel Marinho Pereira ${ }^{5}$ \\ ${ }^{1}$ Departamento de Engenharia Florestal, Universidade Federal dos Vales do Jequitinhonha e Mucuri - UFVJM, \\ Diamantina/MG, Brazil \\ ${ }^{2}$ Departamento de Agronomia, Universidade Federal dos Vales do Jequitinhonha e Mucuri - UFVJM, Diamantina/MG, \\ Brazil \\ ${ }^{3}$ Departamento de Ciências Básicas, Universidade Federal dos Vales do Jequitinhonha e Mucuri - UFVJM, \\ Diamantina/MG, Brazil \\ ${ }^{4}$ Departamento de Agronomia, Universidade Federal de Lavras - UFLA, Lavras/MG, Brazil \\ ${ }^{5}$ Departamento de Engenharia Florestal, Universidade Federal dos Vales do Jequitinhonha e Mucuri - UFVJM, \\ Diamantina/MG, Brazil
}

\begin{abstract}
The objective of this study was to evaluate the initial growth of Eremanthus incanus (Less.) Less (candeia) in soil with manganese doses. Additionally, it sought to assess manganese concentration, and accumulation in the organs of the plant as well as quantify the appropriate concentration of this element in the soil. The experiment was installed in a greenhouse and used manganese doses of $0,50,150$ and $450 \mathrm{mg} \mathrm{kg}^{-1}$ soil. The experimental design used randomized blocks with five replications. Stem diameter and plant height; dry matter of root, shoot and total, and concentration and accumulation of manganese in the leaf, stem and root were evaluated. The manganese concentration in the soil was quantified using the Mehlich-1 and DTPA pH 7.3 extractors. A reduction in growth and high manganese concentrations in all parts of the plant were observed. For Melich-1 extraction the appropriate manganese concentration is $15.90 \mathrm{mg} \mathrm{kg}^{-1}$ and for DTPA it is $3.02 \mathrm{mg} \mathrm{kg}^{-1}$. The use of the candeia for phytoremediation is not recommended due to sensitivity to manganese.
\end{abstract}

Keywords: phytoremediation, degraded areas, heavy metal. 


\section{INTRODUCTION}

Increasing industrialization has led to increased pollution of natural resources, raising significant concerns regarding sustainability. Studies carried out in sites near to industrial complexes have shown high concentrations of heavy metals in the soil, such as manganese $(\mathrm{Mn})$, zinc $(\mathrm{Zn})$, copper $(\mathrm{Cu})$, lead $(\mathrm{Pb})$, and cadmium (Cd), among others, affecting the productivity and biodiversity of ecosystems (Tavares et al., 2013).

Manganese is an essential element for human beings, animals and vegetables (Kemerich et al., 2012). Its main function is during photosynthesis, being responsible for activating enzymes, among them RNA polymerase, which has an indirect role in protein synthesis and cell proliferation (Puga et al., 2011). It also has a fundamental role in cell elongation (Malavolta et al., 1997) and its deficiency can reduce root growth (Prado, 2008). However, excess manganese causes inhibition of chlorophyll biosynthesis, a decline in photosynthetic rate, and induces reactions with oxygen, which can damage the plant cell macromolecules (Rosas et al., 2011).

An excess of manganese can be caused by different factors such as the origin of the soil material, urban waste (domestic and industrial) and organic and chemical fertilizers (Fadigas et al., 2002; Faquin, 2005). The availability of manganese increases with the reduction of $\mathrm{pH}$ and redox potential which may become phytotoxic (Kemerich et al., 2012). Levels of toxicity from manganese are high and variable for uncultivated plants such as tropical trees, which have the ability to fix larger amount of metals in their tissues compared to herbaceous plants and may have great potential for use in revegetation programs for areas contaminated with heavy metals (Marques et al., 2000).

In recent years, there has been a continuous increase in research into effective alternatives for soil rehabilitation (Pereira et al., 2013). One of these alternatives is the phytoremediation process by which plants are introduced into an environment to assimilate contaminants into their roots and leaves (Santos \& Novak, 2013). Considering that not all plant species develop in polluted environments, the first step is to identify the species that besides being appropriate for local conditions, are tolerant of contaminants (Marques et al., 2011).
The Candeia belongs to the Asteraceae family and the ecological group of pioneers, and is considered a forerunner in the colonization of fields (Silva et al., 2008). The plant develops rapidly in open fields with more or less pure stands (Machado et al., 2013). There are several types of Candeia, however, Eremanthus erythropappus (DC.) Macleish and Eremanthus incanus (Less.) Less are more economically important and are more common in Minas Gerais (Pérez et al., 2004; Scolforo et al., 2004). The Eremanthus incanus (Less.) Less (candeia) occurs in savanna areas, secondary forests and caatinga, colonizing low fertility, shallow soils. It plays an important role in the environmental context, forming patches of massive forest in areas with an altitude between 900 and 1,800 m, in places of importance for water table supply (Melo et al., 2012).

In Brazil, there is a need to study phytoremediator species that have still to be commercially exploited (Lamego \& Vidal, 2007; Santos \& Novak, 2013; Amado \& Chaves, 2015). Candeia has characteristics such as resistance to pests and diseases, ease of acquisition of propagules, good adaptability (Accioly et al., 2000); high growth rate and biomass production (Vose et al., 2000); and capacity to develop under adverse conditions (Accioly et al., 2000) that make it a potential phytoremediator.

This study aims to evaluate the initial growth of Eremanthus incanus (Less.) Less (candeia) in soil dosed with manganese, as well as manganese concentration and accumulation in organs. Additionally, it seeks to quantify the appropriate concentration of this element in the soil.

\section{MATERIAL AND METHODS}

The experiment was conducted in a greenhouse in Diamantina-MG (18 ${ }^{\circ} 12^{\prime} \mathrm{S}$; $43^{\circ} 34^{\prime} \mathrm{W}$ and altitude of $1,370 \mathrm{~m}$ ). The soil used was a typical Dystrophic Red Latosol (Embrapa, 2006), medium texture, collected from the surface layer $(0-0,20 \mathrm{~m})$, broken into smaller pieces, air dried and sieved into $5 \mathrm{~mm}$ sieve. A subsample was taken and sieved through a $2 \mathrm{~mm}$ sieve for chemical analysis (Silva, 2009) and soil texture (Embrapa, 1997). The manganese concentration in the soil was determined using Mehlich 1 and DTPA $\mathrm{pH} 7.3$ extractors prior to applying the manganese doses, (Table 1). 
Table 1. Chemical and soil texture analysis before the application of manganese.

\begin{tabular}{|c|c|c|c|c|c|c|c|c|c|c|c|c|c|c|}
\hline $\mathbf{p H} \mathbf{w a t e r}_{\text {w }}$ & $\mathbf{P}$ & $\mathbf{K}$ & $\mathrm{Ca}$ & Mg & Al & $\mathbf{T}$ & $\mathbf{m}$ & V & M & & $\mathrm{CO}$ & Sand & Silt & Clay \\
\hline $2: 1$ & \multicolumn{2}{|c|}{$-\mathrm{mg} \mathrm{dm}^{-3}-$} & \multicolumn{4}{|c|}{--- $\mathrm{cmol}_{\mathrm{c}} \mathrm{dm}^{-3}$} & \multicolumn{2}{|c|}{-- \%-- } & \multicolumn{2}{|c|}{--- $\mathrm{mg} \mathrm{kg}^{-1}$--- } & & $\mathrm{g}$ & & \\
\hline 6.0 & 0.4 & 15.9 & 2.5 & 0.4 & 0.02 & 7.1 & 1 & 41 & $15.9^{(1)}$ & $3.02^{(2)}$ & 1.0 & 460 & 230 & 310 \\
\hline
\end{tabular}

pH water: soil-water relation 1:2,5. P and K: Mehlich Puller 1; Ca, Mg and Al: Puller $\mathrm{KCl} 1 \mathrm{~mol} \mathrm{~L}^{-1}$; T: cation exchange capacity at pH 7.0; m: aluminum saturation; V: Base saturation; Mn: Manganese; CO: organic carbon by Walkey-Black method; Sand, silt and clay: pipette method; ${ }^{(1)}$ Mehlich $1 ;{ }^{(2)} \mathrm{DTPA}$ pH 7.3 .

The seedlings used were grown from seeds collected in different matrices selected in Diamantina-MG region. After processing, the seeds were germinated in plastic tubes containing $55 \mathrm{~cm}^{3}$ of substrate composed of a mixture of three parts, one-third sterile soil, one-third carbonized rice husk and one-third sand (Venturin et al., 2005). Seedlings containing two pairs of leaves and about $4 \mathrm{~cm}$ were selected and removed from the tubes with a subsequent break into small pieces of the substrate, washing the roots in deionized water and transplanting a seedling per polyethylene pot containing $4 \mathrm{~kg}$ of Dystrophic Red Latosol.

Basic fertilization was carried out at planting before the transplantation of the seedlings, as recommended by Amaral et al. (2014) for candeia seedlings in quartzite tailings. Fertilization consisted of: $75 \mathrm{mg} \mathrm{N}$ (ammonium sulfate); $70 \mathrm{mg} \mathrm{P}$ (superphosphate Simple); $75 \mathrm{mg} \mathrm{K}$ (potassium chloride); $0.5 \mathrm{mg} \mathrm{B}$ (boric acid); and $1 \mathrm{mg} \mathrm{Zn}$ (zinc chloride) per $\mathrm{kg}$ of soil with an incubation of 15 days. The manganese was incorporated into the soil in the form of pure manganese chloride for analysis. The manganese doses were applied after soil incubation period with the basic fertilization, 15 days before planting.

The experimental design was in randomized blocks, and the blocking factor the size of seedlings. For this, five blocks were used with manganese treatments at doses of 0, 50, 150 and $450 \mathrm{mg} \mathrm{kg}^{-1}$ soil. Doses were based on the use of guidelines and land use, as indicated by CETESB (2005). Soil moisture was maintained at an equivalent to $60 \%$ of the total pore volume (VTP), as proposed by Freire et al. (1980) and assessed daily by determining the matter of the pots, supplementing the matter with deionized water.

After the end of the experimental period (91 days), stem diameter $(\mathrm{mm})$ and plant height $(\mathrm{cm})$ were evaluated. The stem diameter was measured at neck height with the aid of a digital caliper with a precision of $0.01 \mathrm{~mm}$ and the height was measured from the neck to the apical bud with graduated scale accuracy of $1.0 \mathrm{~mm}$.

After the morphological assessments, seedlings were removed from the pots and the leaves, stem and roots were separated. Initially they were washed in tap water, then immersed in diluted detergent, distilled water, $\mathrm{HCl}$ solution $0.1 \mathrm{~mol} \mathrm{~L}^{-1}$ and deionized water. The collected plant material (shoot and root) was placed in paper bags and laid out to dry in a forced-air oven at $65^{\circ} \mathrm{C}$ for 72 hours until constant matter was obtained. The material was subjected to weighing to determine the dry matter of leaves (MSF), of the stem (MSC), of the root (MSR), of the shoot (MSPA) and total dry matter (MSTO). The growth reduction (\%) for evaluations carried out by comparing doses of manganese with the control $\left(0 \mathrm{mg} \mathrm{kg}^{-1}\right)$ was calculated using the polynomial regression equation by substituting the values of the doses in the equation. Dry matter distribution of root, stem and leaves in plants (\%), depending on the manganese dose was calculated.

To determine the manganese concentration, the collected plant material was dried and ground and then subjected to nitropercloric digestion. The manganese concentration was determined by atomic absorption spectrometry (Malavolta et al., 1997). The accumulated manganese was calculated by the equation (1): $\mathrm{C}=\mathrm{T} \times \mathrm{MS}$, where $\mathrm{C}=$ the accumulated manganese $\left(\mu \mathrm{g}_{\text {plant }}{ }^{-1}\right)$, $\mathrm{T}=$ manganese concentration $\left(\mathrm{mg} \mathrm{g}^{-1}\right)$ and $\mathrm{MS}=$ dry matter $\left(\mathrm{g} \mathrm{plant}^{-1}\right)$. The distribution of the accumulated manganese (\%) was calculated, owing to the different manganese levels.

To quantify the manganese concentration in the soil, at the end of the experiment, the soil was manually homogenized and a sample of about $10 \mathrm{~cm} 3$ per pot was collected. For extraction of manganese Mehlich-1 and DTPA pH 7.3 extractors (Silva, 2009) were used. The manganese concentration was determined by atomic absorption spectrometry (Malavolta et al., 1997). 
The data obtained was submitted to analysis of variance (ANOVA), and a study of polynomial regression according to the manganese doses applied to the soil.

\section{RESULTS AND DISCUSSION}

\subsection{Stem diameter and plant height}

The diameter and height were influenced by manganese doses applied in the soil $(\mathrm{p}<0.01)$. There was a reduction of the variables evaluated with increasing doses of manganese in the soil (Figure 1). By means of the angle coefficients of the equations it appears that the height was more affected by the manganese doses than the diameter. Plants exposed to excessive concentrations of manganese suffered interference in various mechanisms that collaborate to maintain structural and biochemical processes, resulting in different degrees of tissue organization. Such mechanisms cause manganese accumulation in the vacuoles of leaf cells, thereby reducing plant growth (Lavres et al., 2010).

Plant tolerance to manganese is associated with limited absorption, limited translocation to the shoot, and high tolerance for high manganese levels in plant tissues (El Jaoual \& Cox, 1998; Sylvestre et al, 2012.). The greater tolerance of soybean cultivars to excess manganese was associated with the ability to tolerate high internal levels of manganese but not to a possible exclusion mechanism developed by the plant (Komatuda et al., 1993; Sylvestre et al., 2012.). Excess manganese can induce $\mathrm{Fe}$ and $\mathrm{Mg}$ deficiency by inhibiting the absorption or competition at the cellular level and Ca deficiency due to the indirect effect on transporting this to new leaves. Ca transport is mediated by a co-transporter AIA (indolacetic acid) and often tissues with a high manganese concentration have high activity of IAA oxidase, contributing to plant growth reduction due to acid degradation in the tissues (Marschner, 2012).

\subsection{Dry matter production}

The dry matter yield was influenced $(\mathrm{P}<0.01)$ by manganese supply in the soil and control dose provided greater production of dry matter (Figure 2). Through the angular coefficients of equations we observe a greater decrease in total dry matter followed by dry matter of the shoot, dry matter of leaves, dry matter of the root and dry matter of the stem, respectively. For Panicum maximum Jacq. (grass mombaça) subjected to four doses of manganese $\left(0,15,30,60\right.$ and $\left.120 \mathrm{mg} \mathrm{kg}^{-1}\right)$ a greater decrease of dry matter of the shoot in relation to the dry matter of the root was observed (Mingotte et al., 2011). In a study of severity of Triticum aestivum L. (Wheat brown spot) cultivated with different doses of manganese $\left(0,2.5,5,7.5,10,12.5,15,17.5\right.$ and $\left.20 \mathrm{mg} \mathrm{kg}^{-1}\right)$ there were no significant differences in the production of dry matter of the shoot and dry matter of the root depending on the manganese doses (Zanão et al., 2009). According to these authors the manganese concentrations available in the soil were sufficient for adequate biomass production.

Sylvestre et al. (2012) applied manganese doses $\left(0,15,30,60\right.$ and $\left.120 \mathrm{mg} \mathrm{dm}^{-3}\right)$ in soil cultivated with

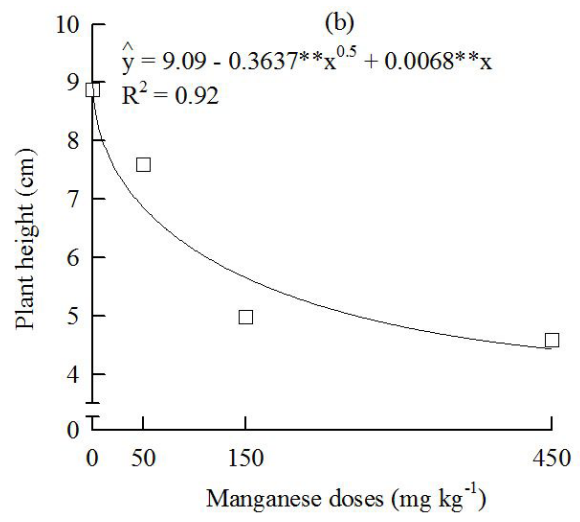

Figure 1. Stem diameter (a) and plant height (b) in response to manganese doses applied in Hapludox clay soils, evaluated at 91 days after transplanting the candeia seedlings ( ${ }^{* *}$ significant at $1 \%$ by the $\mathrm{F}$ test). 


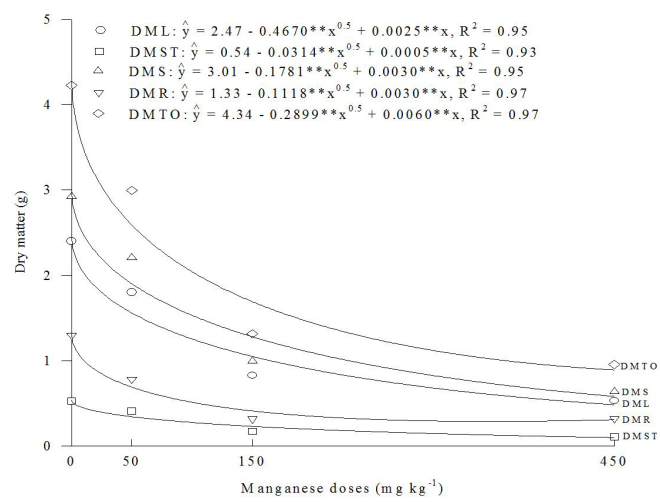

Figure 2. Dry matter production of leaves (DML), stem (DMST), root (DMR), the shoot (DMS) and total (DMTO) in response to manganese doses applied in Hapludox clay soils, evaluated at 91 days after transplanting the candeia seedlings. (** Significant at $1 \%$ by the $\mathrm{F}$ test).

Panicum maximum Jacq. Cv. Tanzania (Tanzania grass) and had higher dry matter of the shoot at a dose of $0 \mathrm{mg}$ manganese $\mathrm{kg}^{-1}$. This result was similar to the one found in this study. The manganese concentration that causes toxicity varies between plant species, probably because manganese tolerance mechanisms involve different, specific biochemical pathways for each genotype (El-Jaoual \& Cox, 1998).

The reduction of growth for dry matter production was directly proportional to the applied dose (Table 2). These results were similar to studies with Eucalyptus urophylla and Eucalyptus saligna grown on substrates with high manganese concentration and different pHs (Magalhães et al., 2012). There was a reduction of $98 \%, 95 \%$ and $96 \%$, for dry matter of leaves, dry matter of the stem and dry matter of the root, respectively. According to these authors, the concentration of manganese in the substrate was above the values corresponding to those considered critical for plant development.

Regarding the distribution of dry weight of root, stem and leaf plants (\%), there was little variation in different doses (Figure 3). Dry matter of the root presented the lowest values in the intermediate doses (50 and $150 \mathrm{mg}$ manganese $\mathrm{kg}^{-1}$ soil) and highest at the highest dose (450 mg manganese $\mathrm{kg}^{-1}$ soil). Therefore it can be inferred that the Eremanthus incanus (Less.) Less (candeia) has not been able to limit the translocation of manganese from the root to the shoot. Assessing the
Table 2. Reduced production of dry matter (\%) leaves (DML), stem (DMST), the shoot (DMS), root (DMR) and total (DMTO) compared to the control $\left(0 \mathrm{mg} \mathrm{kg}^{-1}\right)$ in response to manganese doses applied in Hapludox clay soils, evaluated 91 days after transplanting the candeia seedlings.

\begin{tabular}{|c|c|c|c|c|c|}
\hline 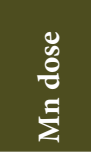 & 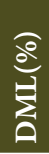 & $\frac{\widehat{e}}{e^{\infty}}$ & $\frac{\widehat{e}}{\sum_{0}^{\infty}}$ & 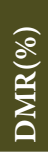 & 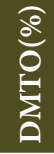 \\
\hline $\mathrm{mg} \mathrm{kg}^{-1}$ & $\ldots$. & $\ldots$. & $\%$. & $\ldots \ldots$. & $\ldots \ldots$ \\
\hline 0 & - & - & - & - & \\
\hline 50 & 19 & 37 & 37 & 48 & 41 \\
\hline 150 & 39 & 57 & 58 & 69 & 61 \\
\hline 450 & 86 & 82 & 81 & 77 & 80 \\
\hline
\end{tabular}

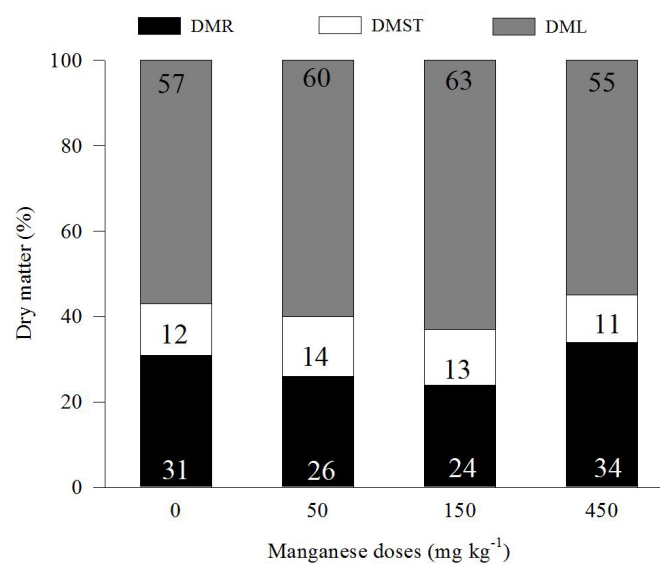

Figure 3. Distribution of dry matter (\%) leaves (DML), stem (DMST), root (DMR), total dry matter in plants (g) in response to manganese doses given to Hapludox clay soils, evaluated at 91 days after transplanting the candeia seedlings.

translocation of manganese, soybean and barley a low redistribution of manganese from the roots to the leaves was observed when plants were grown under conditions of excessive manganese levels (Tsukamoto et al., 2006; Lavres et al., 2008).

\subsection{Manganese concentration in the dry matter}

According to the linear coefficients of adjusted regression equations (Figure 4), higher manganese concentration in dry leaf matter is observed, followed by the stem and root. The manganese concentrations increased linearly in all parts of the plant. For dry matter of leaves, the manganese concentration ranged 
from $332.2 \mathrm{mg} \mathrm{kg}^{-1}$ in control dose to $8512.5 \mathrm{mg} \mathrm{kg}^{-1}$ at the highest dose. For dry matter of the stem, concentrations ranged from $31.1 \mathrm{mg} \mathrm{kg}^{-1}$ to $3773.2 \mathrm{mg} \mathrm{kg}^{-1}$ and in the dry matter of roots, the concentration ranged from $6.22 \mathrm{mg} \mathrm{kg}^{-1}$ to $752.3 \mathrm{mg} \mathrm{kg}^{-1}$.

In tree species, Cordia africana Lam. (córdia-africana), Mimosa caesalpineafolia Benth. (sabiá), Acacia angustissima (Mill.) Ktze. (acácia) and Anadenanthera colubrina (Vell.) Brenan (angico branco), the highest levels of manganese occurred in the dry matter of leaves followed by dry matter of the stem and dry matter of the root (Pereira et al., 2012). Similar results were found in the present study. At the cellular level, tissue tolerance to high manganese may occur through the accumulation of the element in the vacuoles, cell walls or vesicles of Golgi (Lidon \& Teixeira, 2000; Sylvestre et al., 2012). The highest production of dry matter occurred at a control dose $\left(0 \mathrm{mg} \mathrm{kg}^{-1}\right)$ for all fractions of dry matter. It is suggested, therefore, that the proper manganese concentration to the Eremanthus incanus (Less.) Less (candeia) is $332.16 \mathrm{mg} \mathrm{kg}^{-1}$ for dry matter of leaves, $31.13 \mathrm{mg} \mathrm{kg}^{-1}$ for dry matter of the stem and $6.22 \mathrm{mg} \mathrm{kg}^{-1}$ for dry matter of the root. In general, the manganese concentrations in dry matter of several species are above the appropriate range from 20 to $100 \mathrm{mg} \mathrm{kg}^{-1}$ and the critical level of $20 \mathrm{mg} \mathrm{kg}^{-1}$ (Lima et al., 2004). These authors, studying the relations

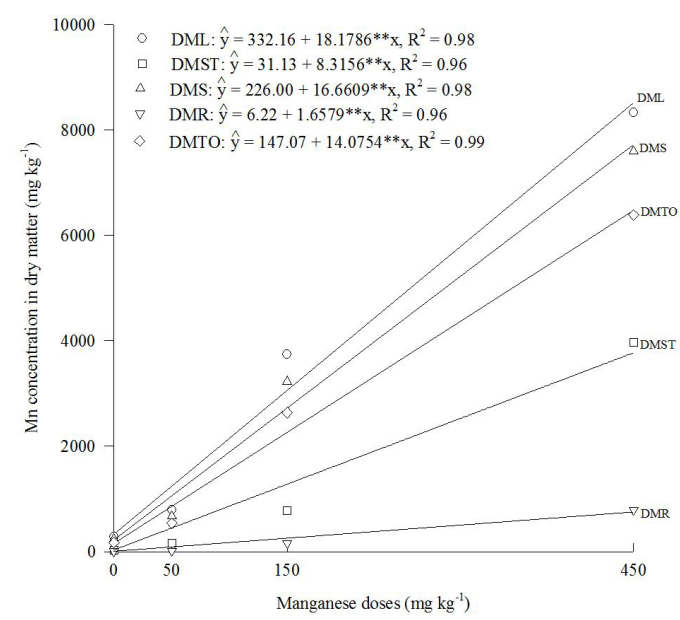

Figure 4. Manganese concentration in dry matter of leaves (DML), stem (DMST), the shoot (DMS), root (DMR) and total (DMTO) in response to manganese doses applied in Hapludox clay soils, evaluated at 91 days after transplanting the candeia seedlings. (** Significant at $1 \%$ by the $\mathrm{F}$ test). between limestone and manganese doses in soybeans defined adequate manganese concentrations in dry matter of leaves of $324 \mathrm{mg} \mathrm{kg}^{-1}$ for the first crop and $387 \mathrm{mg} \mathrm{kg}^{-1}$ for the second crop.

\subsection{Manganese accumulation in the dry matter}

There was a linear increase in manganese accumulation (Equation 1) for dry matter of the stem and dry matter of the root. Dry matter of leaves increased up to the dose of $389.1 \mathrm{mg} \mathrm{kg}^{-1}$, followed by a reduction (Figure 5). This reduction in dry matter of leaves occurred due to low dry matter production values found from this dose. Similar results were found in Luffa cylindrica (bucha) with higher manganese accumulation in the dry matter of leaves (Siqueira et al., 2009). In studies of two species of Eucalyptus urophylla, and Eucalyptus saligna, in soil with high concentrations of manganese, more than $60 \%$ of the accumulated manganese was found in the dry matter of leaves (Magalhães et al., 2012).

Dry matter of leaves presented the maximum accumulation of 4508.6 ug plant $^{-1}$. For dry matter of the stem the maximum value was $423 \mathrm{ug}$ plant $^{-1}$ and the dry matter of the root $1201.5 \mathrm{ug} \mathrm{plant}^{-1}$. In a coal beneficiation area, an accumulation of $816 \mathrm{ug} \mathrm{g}^{-1}$ in the dry matter of the shoot of Typha domingensis (taboa) was observed. High concentrations of heavy

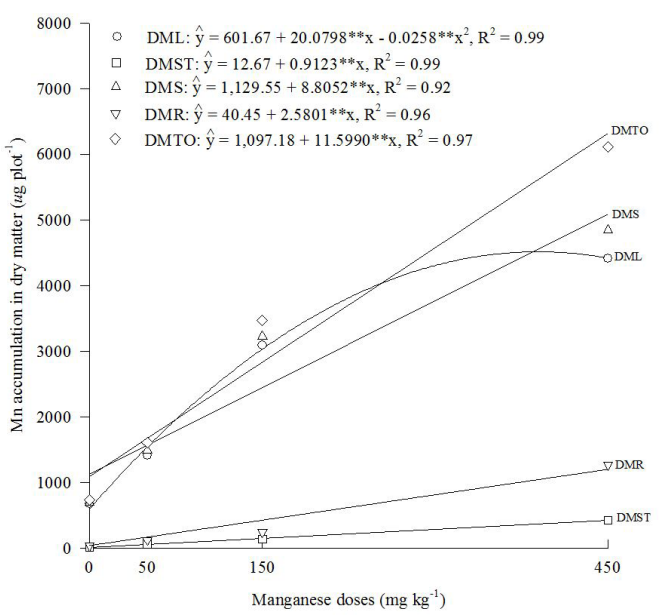

Figure 5. Manganese accumulation in dry matter of leaves (DML), stem (DMST), shoot (DMS), root (DMR) and total (DMTO) in response to the manganese doses applied on Hapludox clay soils evaluated at 91 days after transplanting the candeia seedlings (** Significant at $1 \%$ by F test). 
metals in the middle involve high concentrations in plants. However, as absorption and concentration are specific and vary from organ to organ, different plants accumulate heavy metals in their organs differently (Zocche et al., 2010).

Regarding the distribution of manganese in the dry matter (Figure 6a), it showed an increase in the accumulated amount in the dry matter of the root and a decrease in the dry matter of leaves, with increasing manganese doses. Proportionally, the dry matter of the root increased at the highest manganese doses (Figure 6b). The reduction in manganese accumulation in the dry matter of leaves and the dry matter of the root increased due to the provision of a toxic amount of manganese to the leaves, the highest dose applied, inducing senescence. Thus, manganese cannot be translocated, it is retained in the roots.

\subsection{Manganese concentrations in the soil}

Manganese concentrations in the soil obtained from the Mehlich-1 and DTPA pH 7.3 extractors, showed a linear growth with increasing manganese doses and Mehlich-1 extractor was more efficient (Figure 7). The acid character of the Mehlich-1 extractor enabled
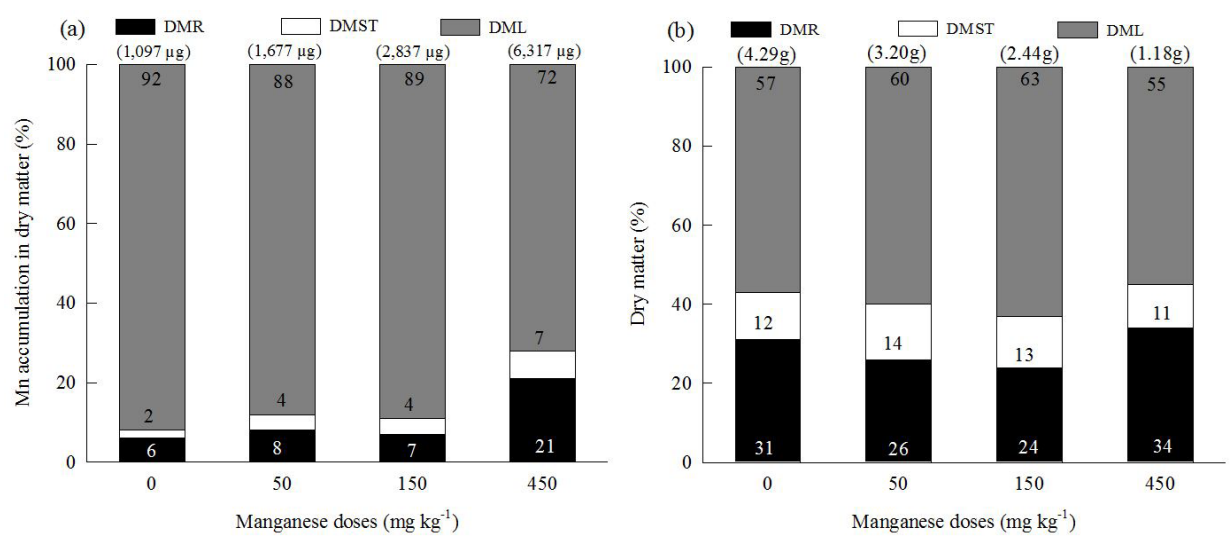

Figure 6. Percentage distribution (a) manganese accumulation in roots (DMR), stem (DMST) and leaves (DML), and (b) dry matter of roots (DMR), stem (DMST), leaves (DML), in response to manganese doses applied in Hapludox clay soils, evaluated 91 days after transplanting the candeia seedlings. The numbers in parentheses represent the manganese total accumulated (a) and total dry matter (b).
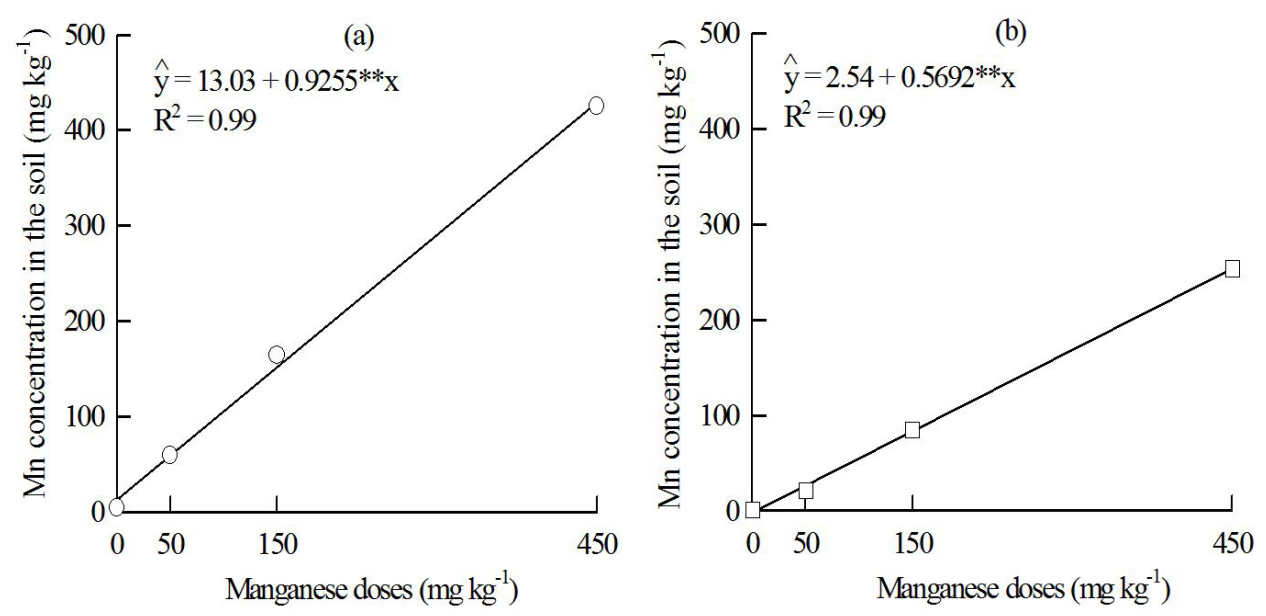

Figure 7. Manganese concentration by Mehlich-1 (a) and DTPA at pH 7.3 (b) extractor in response to manganese doses applied on Hapludox clay soils evaluated 91 days after transplanting the candeia seedlings (** Significant at $1 \%$ by $\mathrm{F}$ test). 
removal of the exchangeable metals in the solid phase, in the solution and also in the complex phases, while the DTPA solution is a chelating agent, and extracted the element only from the labile portion of the ground (Pereira et al., 2012).

The highest production of dry matter occurred at a control dose $\left(0 \mathrm{mg} \mathrm{kg}^{-1}\right)$ for all fractions of dry matter. Therefore the correct manganese concentration in the soil for the Eremanthus incanus (Less.) Less (candeia) is $15.90 \mathrm{mg} \mathrm{kg}^{-1}$ for the Melich-1 extractor and $3.02 \mathrm{mg} \mathrm{kg}^{-1}$ for the DTPA extractor. Suitable manganese soil concentrations for Eremanthus incanus (Less.) Less (candeia) are below the levels suggested by Fernandes et al. (2007). These authors reviewed the concentration of heavy metals in the soil in cities in Minas Gerais considered as significant for the production of olerículas cultures. There, manganese values ranging from 70 to $1756 \mathrm{mg} \mathrm{kg}^{-1}$ were found in the soil, using the DTPA extractor at $\mathrm{pH}$ 7.3. In the study of natural levels of heavy metals in the soils of Minas Gerais state as support for the establishment of Quality Benchmarks, an average value of manganese greater than $200 \mathrm{mg} \mathrm{kg}^{-1}$ for Argisol, Cambisol and Latosol (Caires, 2009) was reported.

\section{CONCLUSIONS}

The initial growth of the Candeia is reduced by the increase of manganese due to increased levels and accumulation of this element in the plant. Candeia shows sensitivity to manganese, which prevents its use for phytoremediation.

\section{SUBMISSION STATUS}

Received: 27 sept., 2016

Accepted: 8 apr., 2017

\section{CORRESPONDENCE TO}

\section{Fillipe Vieira de Araújo}

Departamento de Engenharia Florestal,

Universidade Federal dos Vales do Jequitinhonha e Mucuri - UFVJM, Rodovia MGT 367, Km 583, 5000, Alto da Jacuba, CEP 39100-000, Diamantina, MG, Brazil e-mail: fillipe.vieira10@gmail.com

\section{REFERENCES}

Accioly AMA, Siqueira JO, Novais RF, Alvarez VH, Schaefer CEGR. Contaminação química e biorremediação do solo: tópicos em ciência do solo. Viçosa: Sociedade Brasileira de Ciência do Solo; 2000.

Amado S, Chaves JT Fo. Fitorremediação: uma alternativa sustentável para remedição de solos contaminados por metais pesados. Natureza Online 2015; 13(4): 158-164.

Amaral CS, Silva EB, Pereira IM, Nardis BO, Gonçalves $\mathrm{NH}$, Amaral WG. Crescimento da candeia pela adubação mineral e orgânica em rejeito da mineração de quartzito. Floresta 2014; 44(3): 421-430. http://dx.doi.org/10.5380/ rf.v44i3.32250.

Caires, SM. Determinação dos teores naturais de metais pesados em solos do Estado de Minas Gerais como subsídio ao estabelecimento de Valores de Referência de Qualidade [thesis]. Viçosa: Departamento de Ciência do Solo, Universidade Federal de Viçosa; 2009.

Companhia Ambiental do Estado de São Paulo - CETESB. Decisão de diretoria No 195-2005-E, de 23 de novembro de 2005. São Paulo: CETESB; 2005. [cited 2014 June 10]. Available from: http://www.cetesb.sp.gov.br/Solo/ relatorios/tabela_valores_2005.pdf

El-Jaoual T, Cox DA. Manganese toxicity in plants. Journal of Plant Nutrition 1998; 21(2): 353-386. http://dx.doi. org/10.1080/01904169809365409.

Empresa Brasileira de Pesquisa Agropecuária - Embrapa. Centro Nacional de Pesquisa de Solos. Manual de métodos de análise do solo. Brasília: Produção de Informação; 1997. $212 \mathrm{p}$.

Empresa Brasileira de Pesquisa Agropecuária - Embrapa. Centro Nacional de Pesquisa de Solos. Sistema brasileiro de classificação de solos. Brasília: SPI; 2006.

Fadigas FS, Amaral NMB So, Mazur N, Anjos LHC, Freixo AA. Concentrações naturais de metais pesados em algumas classes de solos brasileiros. Bragantia 2002; 61(2): 151-159. http://dx.doi.org/10.1590/S0006-87052002000200008.

Faquin V. Nutrição mineral de plantas. 1st ed. Lavras: UFLA/FAEPE; 2005.

Fernandes RBA, Luz WV, Fontes MPF, Fontes LEF. Avaliação da concentração de metais pesados em áreas olerícolas no Estado de Minas Gerais. Revista Brasileira de Engenharia Agrícola e Ambiental 2007; 11(1): 81-93. http://dx.doi.org/10.1590/S1415-43662007000100011.

Freire JC, Ribeiro MAV, Bahia GV, Lopes AS, Aquino LH. Resposta do milho cultivado em casa de vegetação a níveis de água em solo da região de Lavras, MG. Revista Brasileira de Ciência do Solo 1980; 4(1): 5-8.

Kemerich PDC, Borba WF, Silva R, Barros G, Gerhardt AE, Flores $\mathrm{CEB}$. Valores anômalos de metais pesados 
em solo de cemitério. Revista Ambiente \& Água 2012; 7(1): 140-156. http://dx.doi.org/10.4136/ambi-agua.838.

Komatuda CRN, Sediyama CS, Novais RF, Monnerat PH, Neves JCL. Comportamento de cultivares de soja sob deficiência ou excesso de manganês em solução nutritiva. Revista Brasileira de Ciência do Solo 1993; 17(1): 217-221.

Lamego FP, Vidal RA. Fitorremediação: plantas como agentes de despoluição? Revista de Ecotoxicologia e Meio Ambiente 2007; 17(1): 9-18.

Lavres J Jr, Moraes MF, Cabral CP, Malavolta E. Influência genotípica na absorção e na toxidez de manganês em soja. Revista Brasileira de Ciência do Solo 2008; 32(1): 173-181. http://dx.doi.org/10.1590/S0100-06832008000100017.

Lavres J Jr, Reis AR, Rossi ML, Cabral CP, Nogueira CL, Malavolta E. Changes in the ultrastructure of soybean cultivars in response to manganese supply in solution culture. Scientia Agrícola 2010; 67(3): 287-294. http:// dx.doi.org/10.1590/S0103-90162010000300006.

Lidon FC, Teixeira MG. Rice tolerance to excess Mn: implications in the chloroplast lamellae and synthesis of a novel Mn protein. Plant Physiology and Biochemistry 2000; 38(12): 969-978. http://dx.doi.org/10.1016/S09819428(00)01207-9.

Lima DV, Kliemamann HJ, Moraes MF, Leandro WM. Relações entre doses de calcário e manganês na nutrição mineral da soja na região de Rio Verde-GO. Pesquisa Agropecuária Tropical 2004; 34(2): 65-73.

Machado NAM, Leite MGP, Figueiredo MA, Kozovits AR. Growing Eremanthus erythropappus in crushed laterite: A promising alternative to topsoil for bauxitemine revegetation. Journal of Environmental Management 2013; 129(1): 149-156. PMid:23920415. http://dx.doi. org/10.1016/j.jenvman.2013.07.006.

Magalhães MOL, Amaral NMB So, Mazur N, Machado HM, Sampaio J Jr. Desempenho de duas espécies de eucalipto em solo com elevados teores de Mn. Revista Brasileira de Engenharia Agrícola e Ambiental 2012; 16(1): 92-98. http://dx.doi.org/10.1590/S1415-43662012000100012.

Malavolta E, Vitti GC, Oliveira SA. Avaliação do estado nutricional das plantas:princípios e aplicações. 2. ed. Piracicaba: POTAFOS; 1997.

Marques M, Aguiar CRC, Silva JJLS. Desafios técnicos e barreiras sociais, econômicas e regulatórias na fitorremediação de solos contaminados. Revista Brasileira de Ciência do Solo 2011; 35(1): 1-11. http://dx.doi.org/10.1590/S010006832011000100001.

Marques TCLLSM, Moreira FMS, Siqueira JO. Crescimento e teor de metais de mudas de espécies arbóreas cultivadas em solo contaminado com metais pesados. Pesquisa Agropecuária Brasileira 2000; 35(1): 121-132. http://dx.doi. org/10.1590/S0100-204X2000000100015.

Marschner P. Mineral nutrition of higher plants. 3. ed. New York: Academic Press; 2012.
Melo LA, Davide AC, Teixeira LAF. Metodologia para resgate de matrizes e enraizamento de estacas de Eremanthus erythropappus. Cerne 2012; 18(4): 631-638. http://dx.doi. org/10.1590/S0104-77602012000400013.

Mingotte FLC, Santos CLR, Prado RM, Flores RA, Togoro $\mathrm{AH}$, Silva JAS et al. Manganese in the nutrition and dry mass production of the Mombaça grass. Bioscience Journal 2011; 27(6): 879-887.

Pereira ACC, Rodrigues ACD, Santos FS, Guedes JN, Amaral NMB So. Concentração de metais pesados em espécies arbóreas utilizadas para revegetação de área contaminada. Revista Ciência Agronômica 2012; 43(4): 641-647. http:// dx.doi.org/10.1590/S1806-66902012000400004.

Pereira KL, Pinto LVA, Pereira AJ. Potencial fitorremediador das plantas predominantes na área do lixão de Inconfidentes/ MG. Revista Agrogeoambiental 2013; 1(1): 25-29. http:// dx.doi.org/10.18406/2316-1817v1n12013566.

Pérez JFM, Scolforo JRS, Oliveira AD, Mello JM, Borges LFR, Camolesi JF. Sistema de manejo para a candeia Eremanthus erythropappus (DC.) Macleish, a opção do sistema de corte seletivo. Cerne 2004; 10(2): 257-273.

Prado RM. Manual de nutrição de plantas forrageiras. 1. ed. Jaboticabal: FUNEP; 2008.

Puga AP, Prado RM, Melo DM, Guidi IM, Ortega K, Cardoso SS et al. Efeitos da aplicação de manganês no crescimento, na nutrição e na produção de matéria seca de plantas de Brachiaria brizantha (cv. MG4). Revista Ceres 2011; 58(6): 811-816. http://dx.doi.org/10.1590/ S0034-737X2011000600019.

Rosas A, Rengel Z, Ribera A, Mora MLL. Phosphorus nutrition alleviates manganese toxicity in Lolium perenne and Trifolium repens. Journal of Plant Nutrition and Soil Science 2011; 174(1): 210-219. http://dx.doi.org/10.1002/ jpln.201000104.

Santos CF, Novak E. Plantas nativas do cerrado e possibilidades em fitorremediação. Revista de Ciências Ambientais 2013; 7(1): 68-79.

Scolforo JRS, Pérez JFM, Camolesi JF, Borges LFR, Acerbi FW. Estimativas de volume, peso seco, peso de óleo e quantidade de moirões para a candeia (Eremanthus erythropappus (DC.) MacLeish). Cerne 2004; 10(1): 87-102.

Silva FC. Manual de análises químicas de solos, plantas e fertilizantes. 2. ed. Brasília: Embrapa Informações Tecnológicas; 2009.

Silva MA, Mello JM, Scolforo JRS, Czanck L Jr, Andrade IS, Oliveira AD. Análise da distribuição espacial da candeia (Eremanthus erythropappus (DC.) MacLeish) sujeita ao sistema de manejo porta-sementes. Cerne 2008; 14(4): 311-316.

Siqueira RG, Santos RHS, Martinez HEP, Cecon PR. Crescimento e acúmulo de nutrientes em bucha vegetal (Luffa cylindrica). Revista Ceres 2009; 56(5): 685-696. 
Sylvestre TB, Kuhnen F, Silva ER, Martins PES, Galatti FS, Prado MR. Resposta do capim-tanzânia à aplicação de manganês. Bioscience Journal 2012; 28(5): 684-691.

Tavares SRL, Oliveira AS, Salgado CM. Avaliação de espécies vegetais na fitorremediação de solos contaminados por metais pesados. Holos 2013; 5(29): 80-97. http://dx.doi. org/10.15628/holos.2013.1852.

Tsukamoto T, Nakanishi H, Kiyomiya S, Watanabe S, Matsuhashi S, Nishizawa NK et al. ${ }^{52} \mathrm{Mn}$ translocation in barley monitored using apositron-emitting tracer imaging system. Soil Science and Plant Nutrition 2006; 52(6): 717725. http://dx.doi.org/10.1111/j.1747-0765.2006.00096.x.

Venturin N, Souza PA, Macedo RLG, Nogueira FD. Adubação mineral da candeia (Eremanthus erythropappus (DC.) McLeisch). Floresta 2005; 35(2): 211-219. http:// dx.doi.org/10.5380/rf.v35i2.4606.
Vose JM, Swank WT, Harvey GJ, Clinton D, Sobek S. Leaf water relations and sapflow in Eastern cottonwood (Populus detoides Bartr.) trees planted for phytoremediation of a groundwater pollutant. International Journal of Phytoremediation 2000; 2(1): 53-73. http://dx.doi. org/10.1080/15226510008500030.

Zanão LA Jr, Rodrigues FA, Fontes RLF, Korndörfer GH, Neves JCL. Rice resistance to brown spot mediated by silicon and its interaction with manganese. Journal of Phytopathology 2009; 157(2): 73-78. http://dx.doi. org/10.1111/j.1439-0434.2008.01447.x.

Zocche JJ, Freitas M, Quadros KE. Concentração de Zn e Mn nos efluentes do beneficiamento de carvão mineral e em Typha domingensis PERS (TYPHACEAE). Revista Árvore 2010; 34(1): 177-188. http://dx.doi.org/10.1590/ S0100-67622010000100019. 